\title{
Nucleation and Precipitation Strengthening in Dilute Al-Ti and Al-Zr Alloys
}

\begin{abstract}
KEITH E. KNIPLING, DAVID C. DUNAND, and DAVID N. SEIDMAN
Two conventionally solidified Al- $0.2 \mathrm{Ti}$ alloys (with 0.18 and 0.22 at. pet Ti) exhibit no hardening after aging up to 3200 hours at $375{ }^{\circ} \mathrm{C}$ or $425{ }^{\circ} \mathrm{C}$. This is due to the absence of $\mathrm{Al}_{3} \mathrm{Ti}$ precipitation, as confirmed by electron microscopy and electrical conductivity measurements. By contrast, an $\mathrm{Al}-0.2 \mathrm{Zr}$ alloy (with 0.19 at. pct $\mathrm{Zr}$ ) displays strong age hardening at both temperatures due to precipitation of $\mathrm{Al}_{3} \mathrm{Zr}\left(\mathrm{Ll}_{2}\right)$ within $\mathrm{Zr}$-enriched dendritic regions. This discrepancy between the two alloys is explained within the context of the equilibrium phase diagrams: (1) the disparity in solid and liquid solubilities of Ti in $\alpha-\mathrm{Al}$ is much greater than that of $\mathrm{Zr}$ in $\alpha$-Al; and (2) the relatively small liquid solubility of Ti in $\alpha$-Al limits the amount of solute retained in solid solution during solidification, while the comparatively high solid solubility reduces the supersaturation effecting precipitation during post-solidification aging. The lattice parameter mismatch of $\mathrm{Al}_{3} \mathrm{Ti}\left(\mathrm{Ll}_{2}\right)$ with $\alpha$ - $\mathrm{Al}$ is also larger than that of $\mathrm{Al}_{3} \mathrm{Zr}\left(\mathrm{Ll}_{2}\right)$, further hindering nucleation of $\mathrm{Al}_{3} \mathrm{Ti}$. Classical nucleation theory indicates that the minimum solute supersaturation required to overcome the elastic strain energy of $\mathrm{Al}_{3} \mathrm{Ti}$ nuclei cannot be obtained during conventional solidification of $\mathrm{Al}-\mathrm{Ti}$ alloys (unlike for $\mathrm{Al}-\mathrm{Zr}$ alloys), thus explaining the absence of $\mathrm{Al}_{3} \mathrm{Ti}$ precipitation and the presence of $\mathrm{Al}_{3} \mathrm{Zr}$ precipitation.
\end{abstract}

DOI: $10.1007 / \mathrm{s} 11661-007-9283-6$

(C) The Minerals, Metals \& Materials Society and ASM International 2007

\section{INTRODUCTION}

THE Group 4 transition metals (Ti, Zr, or $\mathrm{Hf}$ ) constitute a group of alloying additions to $\mathrm{Al}$ that show particular promise for developing creep-resistant, thermally stable Al-based alloys. ${ }^{[1]}$ In each of these systems, an ordered $\mathrm{Al}_{3} \mathrm{M}(\mathrm{M}=\mathrm{Ti}, \mathrm{Zr}$, or $\mathrm{Hf})$ trialuminide may be precipitated from a supersaturated solid solution during post-solidification aging. While the equilibrium structure of these $\mathrm{Al}_{3} \mathrm{M}$ trialuminides is tetragonal $\left(\mathrm{D}_{22}\right.$ or $\left.\mathrm{D}_{23}\right)$, decomposition of supersaturated Al-M solid solutions occurs initially by the formation of nanometer-scale metastable cubic $\mathrm{Al}_{3} \mathrm{M}$ $\left(\mathrm{L1}_{2}\right)$ precipitates exhibiting small lattice parameter mismatches with $\alpha$-Al, which transform to their respective equilibrium tetragonal structures after prolonged aging (approximately 100 to 1000 hours) at elevated temperatures $\left(>450{ }^{\circ} \mathrm{C}\right)$. Moreover, these transition elements are anomalously slow diffusers in $\alpha$-Al, with very limited equilibrium solid solubilities, enabling precipitated $\mathrm{Al}_{3} \mathrm{M}$ to be resistant to Ostwald ripening

KEITH E. KNIPLING, formerly with the Department of Materials Science and Engineering, Northwestern University, Evanston, IL 60208-3108, National Research Council Associate, is with the Naval Research Laboratory, Washington, DC 20375-5320, USA. Contact e-mail: knipling@anvil.nrl.navy.mil DAVID C. DUNAND, James and Margie Krebs Professor of Materials Science and Engineering, is with the Department of Materials Science and Engineering, Northwestern University, Evanston, IL 60208-3108, USA. DAVID N. SEIDMAN, Walter P. Murphy Professor of Materials Science and Engineering, is with the Department of Materials Science and Engineering and Northwestern University, Evanston, IL 60208-3108, USA. Center for Atom-Probe Tomography (NUCAPT), Northwestern University.

Manuscript submitted December 15, 2006.

Article published online September 13, 2007. in accordance with volume diffusion-controlled coarsening models. ${ }^{[1]}$

For high-temperature applications, Ti seems especially promising as an alloying addition among the Group 4 elements because it has the smallest atomic weight and the smallest diffusivity in $\alpha-\mathrm{Al} .{ }^{[1]}$ Indeed, $\mathrm{Al}$ alloys reinforced by $\mathrm{Al}_{3} \mathrm{Ti}$ dispersions have garnered considerable interest as potential lightweight, hightemperature structural materials, and the thermal stability and strength at high temperatures of these alloys is well documented. ${ }^{[2-18]}$ These studies, however, investigated alloys prepared by rapid solidification processing $(\mathrm{RSP})^{[2-8]}$ or mechanical alloying (MA) $)^{[2,9-18]}$ techniques, whose nonequilibrium processing routes circumvent the difficulties encountered during conventional solidification of Al-Ti alloys.

The problems with casting these alloys arise from the fact that $\mathrm{Al}_{3} \mathrm{M}(\mathrm{M}=\mathrm{Ti}, \mathrm{Zr}$, or $\mathrm{Hf})$ exhibits a peritectic phase equilibrium with the terminal $\alpha$-Al solid solution. The first solid to form under equilibrium conditions is the properitectic, or primary, $\mathrm{Al}_{3} \mathrm{M}$ ordered phase (for alloys in the peritectic composition range, i.e., those enriched beyond the minimum liquid solubility of solute). These solute-rich primary phases readily nucleate and grow into coarse (approximately $100 \mu \mathrm{m}$ ) precipitates during conventional casting, leaving the remaining melt, and ultimately the solidified $\alpha$-Al solid solution, substantially depleted in solute. This limits the potential for subsequent precipitation strengthening because the supersaturation - and therefore the chemical driving force for solid-state nucleation, as well as the equilibrium volume fraction of the dispersed phase, if formed-is significantly reduced.

Under certain conditions, primary $\mathrm{Al}_{3} \mathrm{M}$ may solidify from the melt with the metastable cubic $\mathrm{Ll}_{2}$ structure. ${ }^{[19]}$ 
These metastable particles are isostructural to, and exhibit a small lattice parameter mismatch with, the $\alpha$-Al solid solution, and therefore act as efficient heterogeneous nucleants during solidification of $\alpha$-Al. The resulting grain refinement in cast alloys is frequently exploited industrially by Ti additions to $\mathrm{Al}^{[19-22]}$ and has also been observed in $\mathrm{Al}-\mathrm{Zr}^{[19,23,24]}$ and $\mathrm{Al}-\mathrm{Hf}^{[25-27]}$ alloys when primary precipitation of $\mathrm{Al}_{3} \mathrm{M}\left(\mathrm{Ll}_{2}\right)$ occurs. The refined grain size, however, is undesirable for applications where creep resistance is required.

This study examines the feasibility of developing conventionally cast and aged, precipitation-strengthened, dilute Al-based alloys alloyed with the Group 4 elements $\mathrm{Ti}$ and $\mathrm{Zr}$, exhibiting a coarse grain size suitable for creep-resistant applications. Most studies related to conventionally solidified Al-Ti alloys have focused on the thermal stability of the relatively coarse primary $\mathrm{Al}_{3}$ Ti phase formed during solidification. ${ }^{[28-32]}$ As noted in References 33 and 34, the scientific literature pertaining to decomposition or age hardening of $\mathrm{Al}-\mathrm{Ti}$ solid solutions produced by conventional ingot metallurgy processing is rather limited. The primary objective, therefore, is to report and discuss the precipitation behavior in dilute Al-Ti alloys, with the data for Al- $\mathrm{Zr}$ provided primarily as a comparison. In a subsequent article, ${ }^{[35]}$ we report in detail on the precipitation behavior and stability of $\mathrm{Al}_{3} \mathrm{Zr}$ in conventionally solidified Al-Zr alloys.

\section{EXPERIMENTAL PROCEDURES}

\section{A. Alloy Compositions and Preparation}

Two Al-Ti and one Al-Zr alloys were cast, with both solutes nominally alloyed at the $0.2 \mathrm{pct}$ level (all compositions are given in at. pct); the exact alloy compositions are Al-0.18Ti, Al-0.22Ti, and Al-0.19Zr, with an estimated error of \pm 0.01 at. pct, as indicated in Table I. Small (approximately $7 \mathrm{~g}$ ) buttons of these alloys were prepared by arc melting in a gettered purified argon atmosphere using a nonconsumable tungsten electrode and a water-cooled copper cathode as the crucible. The charges were melted a minimum of 10 times and inverted between melts to ensure alloy homogeneity. The moderately enhanced cooling rate associated with the chilled crucible was estimated to be of the order of $10-100{ }^{\circ} \mathrm{C} \mathrm{s}^{-1}$. For dilute Al-Ti and Al-Zr alloys, as well as other peritectic systems, to a specific cooling rate corresponds a critical solute concentration below which primary precipitation of $\mathrm{Al}_{3} \mathrm{M}$ $(\mathrm{M}=\mathrm{Ti}$ or $\mathrm{Zr})$ does not occur. ${ }^{[36-38]}$ The compositions

Table I. Designations and Verified Compositions of the Al-Ti and $\mathrm{Al}-\mathrm{Zr}$ Alloys Investigated

\begin{tabular}{llr}
\hline Designation & First Analysis & Second Analysis \\
\hline Al- $0.18 \mathrm{Ti}$ & 0.175 at. pct $\mathrm{Ti}$ & 0.178 at. pct Ti \\
Al-0.22Ti & 0.237 at. pet Ti & 0.211 at. pct Ti \\
Al-0.19Zr & - & 0.186 at. pct $\mathrm{Zr}$ \\
\hline
\end{tabular}

\footnotetext{
* Bodycote Materials Testing.

*** ATI Wah Chang.
}

in Table I were expected, based on prior solidification studies (Figure 8, discussed subsequently), to be near the threshold for avoiding primary precipitation of $\mathrm{Al}_{3} \mathrm{M}$ for the moderate cooling rates used here.

Both Al-Ti alloys were prepared by melting 99.95 at. pct Al (Atlantic Equipment Engineers, Bergenfield, NJ, and containing 257 at. ppm Fe and 260 at. ppm Si as impurities) with a monolithic $\mathrm{Al}_{3} \mathrm{Ti}$ master alloy. A primary advantage of this approach is that the melting point of $\mathrm{Al}_{3} \mathrm{Ti}\left(1350{ }^{\circ} \mathrm{C}\right)$ is lower than that of pure $\mathrm{Ti}$ $\left(1688^{\circ} \mathrm{C}\right)$. Additionally, this ordered structure is a line compound whose composition is entirely homogeneous. This is not true of commercial master alloys (containing typically 5 to $10 \mathrm{wt}$ pct $\mathrm{Ti}$ ) that exhibit coarse (approximately $100 \mu \mathrm{m}$ ) primary $\mathrm{Al}_{3} \mathrm{Ti}$ precipitates. For the dilute alloys in this investigation and the small mass of the button ingots, such inhomogeneous master alloys introduce unacceptable uncertainties in chemical composition. The monolithic $\mathrm{Al}_{3} \mathrm{Ti}$ master alloy was prepared by arc melting the requisite amounts of pure constituents (99.95 pct Al, Atlantic Equipment Engineers; 99.99+ pct Ti, Alfa Aesar, Ward Hill, MA) corresponding to the stoichiometry of the $\mathrm{Al}_{3} \mathrm{Ti}$ phase; chemical homogeneity and structural uniformity of the button ingot was verified using X-ray diffraction.

The Al-0.19Zr alloy was prepared from a dilute master alloy containing $1.9 \mathrm{wt}$ pet $\mathrm{Zr}$, which was dilution-cast from a commercial $10 \mathrm{wt}$ pet $\mathrm{Zr}$ master alloy (KB Alloys, Reading, PA). The chemical compositions of both Al-Ti alloys were verified independently by Bodycote Materials Testing (Skokie, IL) and ATI Wah Chang (Albany, OR), while the composition of Al-0.19Zr was checked by ATI Wah Chang only.

\section{B. Aging Treatments and Analytical Techniques}

Prior to post-solidification aging, sections of each alloy were examined by optical microscopy and scanning electron microscopy (SEM) to verify the assolidified microstructure (porosity and grain size) and to check for the presence of properitectic, or primary, $\mathrm{Al}_{3} \mathrm{M}$ precipitates. The SEM micrographs of the assolidified specimens were obtained with an Hitachi S-3500 instrument (Hitachi High Technologies America, Inc., Pleasanton, CA) operated at an accelerating voltage of $20 \mathrm{kV}$, using a secondary electron detector. The as-cast alloys were isothermally aged at $375^{\circ} \mathrm{C}$ or $425^{\circ} \mathrm{C}$, within the range of temperatures reported to exhibit a strong age hardening response for Al-Ti alloys produced by $\mathrm{RSP}^{[4,6,39,40]}$ or MA ${ }^{[10]}$ and for Al-Zr alloys produced by $\mathrm{RSP}^{[34,41-44]}$ or chill casting. ${ }^{[45,46]}$ Precipitation of $\mathrm{Al}_{3} \mathrm{Ti}$ or $\mathrm{Al}_{3} \mathrm{Zr}$ during aging was monitored by a number of techniques, described subsequently.

First, Vickers microhardness measurements were performed at room temperature on metallographically polished sections using a load of $200 \mathrm{~g}$ and a dwell time of 5 seconds. Second, precipitation of $\mathrm{Al}_{3} \mathrm{Ti}$ or $\mathrm{Al}_{3} \mathrm{Zr}$ was assessed directly by transmission electron microscopy (TEM). The TEM foils were prepared by mechanical grinding sections of aged specimens to a thickness of approximately $100 \mu \mathrm{m}$. Discs of 3-mm diameter were punched from these sections and thinned to perforation by 
twin-jet electropolishing at $20 \mathrm{Vdc}$ (Struers TenuPol-5*)

*Tenupol is a trademark of Struers A/S, Ballerup, Denmark.

using a $10 \mathrm{vol}$ pet solution of perchloric acid in methanol at $-40{ }^{\circ} \mathrm{C}$. Conventional TEM was performed on a Hitachi H-8100 operating at $200 \mathrm{kV}$ or a PHILIPS** CM

**PHILIPS is a trademark of Philips Electronic Instruments Corp., Mahwah, NJ.

30 operating at $300 \mathrm{kV}$, using a double-tilt stage. Electropolished TEM foils were also examined using a $\mathrm{LEO}^{\dagger}$

${ }^{\dagger}$ LEO is a trademark of Zeiss-Leica, Cambridge, England.

1525 high-resolution field-emission gun scanning electron microscope (SEM) operated at $3 \mathrm{kV}$ with a short working distance $(3 \mathrm{~mm})$ using a secondary electron in-lens detector. As discussed subsequently, the alloys are highly segregated on the micrometer scale, which is not easily discerned in TEM. The advantage of SEM as a complement to TEM is the much larger field-of-view from the larger range in magnification, which is compounded by the fact that there is no limitation that the foil be electron transparent. Furthermore, the resolution of the LEO 1525 is capable of resolving nanometer-scale $\mathrm{Al}_{3} \mathrm{Ti}$ or $\mathrm{Al}_{3} \mathrm{Zr}$ precipitates.

Finally, for the Al-Ti alloys, which did not exhibit detectable age hardening or evidence for precipitation of $\mathrm{Al}_{3}$ Ti by electron microscopy (SEM and TEM), electrical conductivity measurements were also performed to monitor the decomposition of the supersaturated solid solutions during extended aging at $425^{\circ} \mathrm{C}$. These measurements were performed using a SIGMATEST 2.069 (Foerster Instruments, Pittsburgh, PA) eddy current apparatus at room temperature. Five measurements were recorded, each corresponding to a different frequency $(60,120,240,480$, and $960 \mathrm{kHz})$, on each specimen. For consistency, a single specimen of each alloy (aged for various times) was used for conductivity measurements.

\section{EXPERIMENTAL RESULTS}

\section{A. Optical Microscopy}

Figure 1 shows the as-cast macrostructure of the alloys studied. The solidification macrostructure is typical of cast alloys, with coarse columnar grains, originating at the bottom surface of the ingot (which was in contact with the chilled copper crucible of the arc melter), growing upward toward a zone of equiaxed grains at the center of the ingot. The relative sizes of the columnar and equiaxed zones is strongly dependent on the solute content of the alloy and, more precisely, the extent of properitectic $\mathrm{Al}_{3} \mathrm{M}(\mathrm{M}=\mathrm{Ti}$ or $\mathrm{Zr}$ ) precipita-

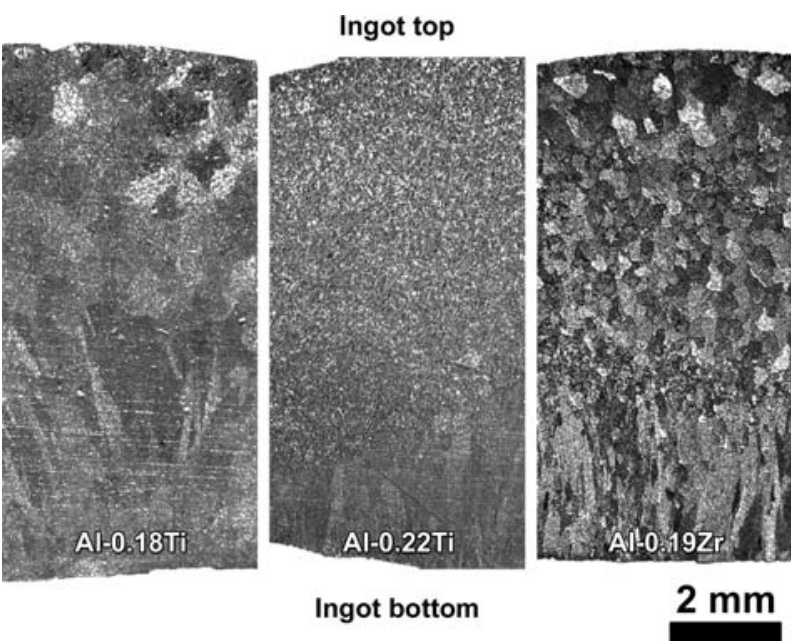

Fig. 1-Longitudinal cross sections of as-cast alloys Al-0.18Ti, Al-0.22Ti, and Al-0.19Zr, showing various degrees of grain refinement (etching with Poultan's reagent).

tion because these primary phases are potent grain refiners, as discussed previously.

Alloy Al-0.18Ti is the most dilute of those studied (Table I), and the extent of the columnar zone, which comprises nearly half of the ingot cross section in this alloy, is also greatest. Within the equiaxed zone, the grains are relatively coarse, with diameters ranging from 0.5 to $1.0 \mathrm{~mm}$. The effect of a small increase in $\mathrm{Ti}$ concentration in these conventionally solidified alloys is demonstrated for Al-0.22Ti, which exhibits a dramatic refinement in grain size with a fine columnar zone that adjoins an even finer equiaxed region of small (50 to $100 \mu \mathrm{m})$ grains in the upper half of the ingot. Moderate grain refinement is also exhibited for Al-0.19Zr, which is intermediate between that of alloy Al-0.18Ti and alloy Al-0.22Ti. The columnar zone of Al-0.19Zr extends for approximately one-third of the ingot cross section, with the bulk of the ingot consisting of equiaxed grains ranging in size from 0.15 to $0.30 \mathrm{~mm}$ in diameter.

The pronounced grain refinement observed in Figure 1 for $\mathrm{Al}-0.22 \mathrm{Ti}$ and $\mathrm{Al}-0.19 \mathrm{Zr}$ is due to copious precipitation of properitectic $\mathrm{Al}_{3} \mathrm{Ti}$ or $\mathrm{Al}_{3} \mathrm{Zr}$ precipitates, which were observed in metallographically polished as-solidified specimens by SEM (Figure 2). The primary properitectic precipitates are 10 to $20 \mu \mathrm{m}$ in diameter and exhibit a petal-like morphology. This morphology is characteristic of the metastable $\mathrm{L}_{2}$ properitectic $\mathrm{Al}_{3} \mathrm{M}$ phase, ${ }^{[19]}$ whose cubic structure is commensurate with fcc $\alpha-\mathrm{Al}$ and acts as an effective heterogeneous nucleant of $\alpha$-Al during solidification, resulting in the grain refinement observed in Figure 1. The refined grain structure is also apparent in Figure 2, as grain boundaries are apparent in both SEM micrographs. The grain boundaries are decorated with Fe-rich precipitates, confirmed by energy-dispersive X-ray spectroscopy in the SEM, and are thought to be a eutectic constituent formed at the end of solidification, as expected because the impurity $\mathrm{Fe}$ concentration is close to the maximum solubility of $\mathrm{Fe}$ in $\alpha$-Al. ${ }^{[47]}$ 


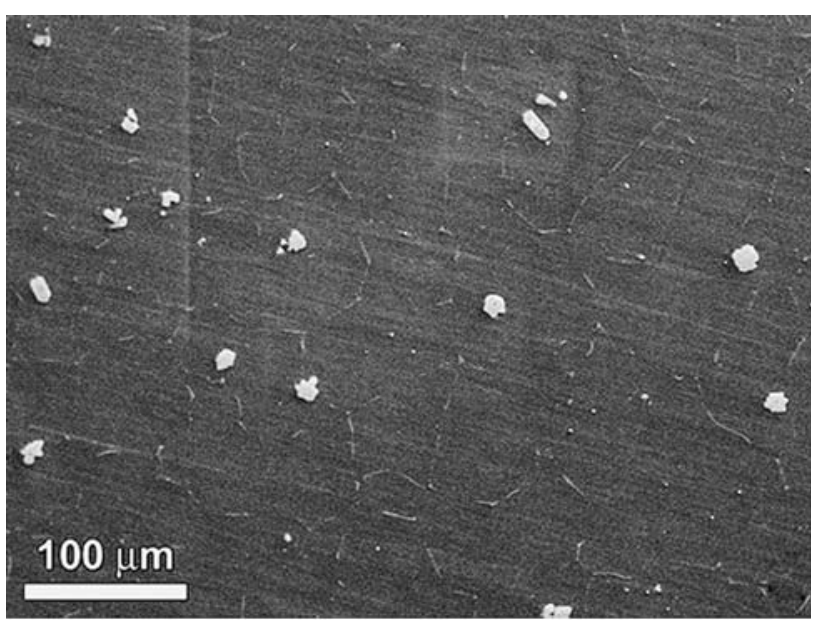

(a)

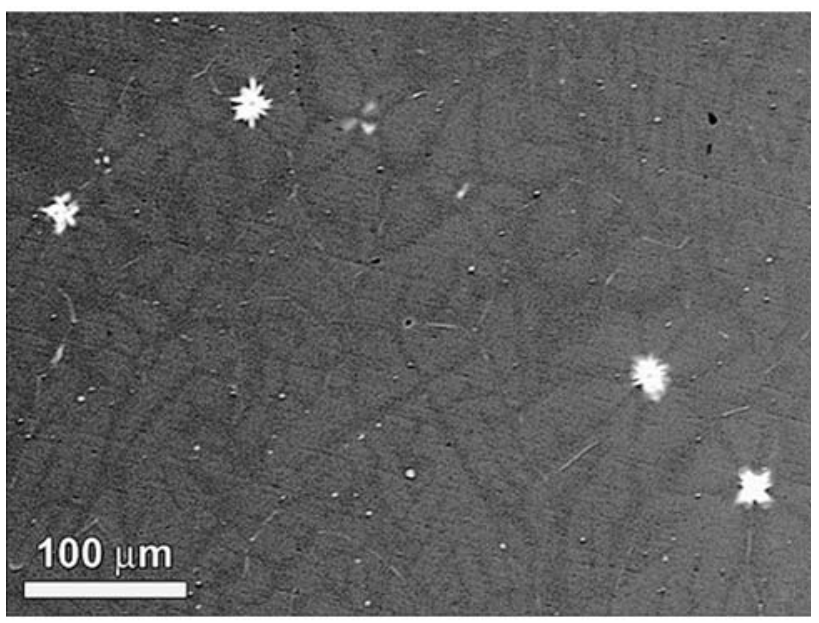

(b)

Fig. 2-SEM secondary electron micrographs of as-solidified $(a)$ $\mathrm{Al}-0.22 \mathrm{Ti}$ and $(b) \mathrm{Al}-0.19 \mathrm{Zr}$. Both alloys exhibit petal-like primary $\mathrm{Al}_{3} \mathrm{Ti}$ or $\mathrm{Al}_{3} \mathrm{Zr}$ precipitates, responsible for the grain refinement observed in Fig. 1. Grain boundaries are visible in both micrographs, and $\mathrm{Zr}$-enriched dendritic cells are apparent in (b).

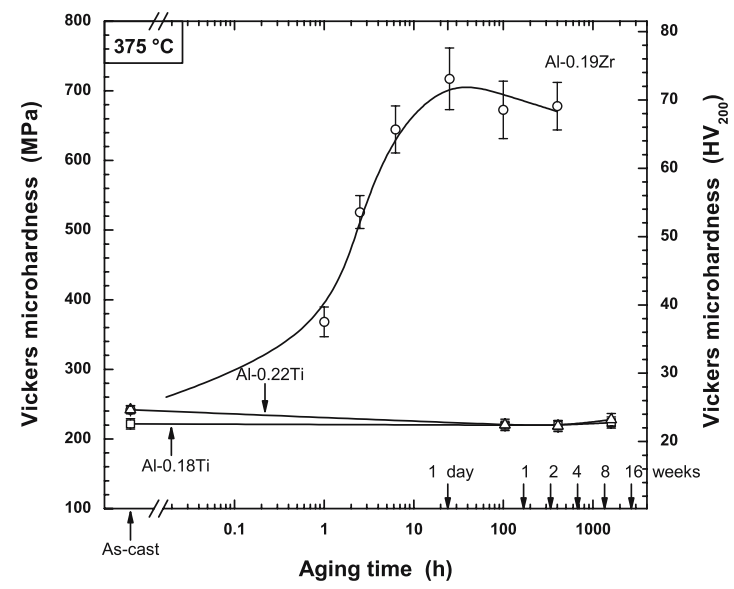

(a)
The presence of the primary precipitates in Figure 2 indicates also that (for the conventional casting conditions used in this study) exceeding approximately 0.2 at. pct solute ( $\mathrm{Ti}$ or $\mathrm{Zr}$ ) results in primary precipitation of $\mathrm{Al}_{3} \mathrm{M}$ and hence does not increase the amount of solute retained in solid solution. In addition to the primary precipitates described previously, Figure 2(b) reveals the Zr-enriched dendrites in as-solidified Al-0.19Zr, which appear lighter due to $Z$-contrast from backscattered electrons. A similar contrast is not as apparent in Al-0.22Ti (Figure 2(a)) because the difference in atomic number between Al (13) and Ti (22) is less than that of $\mathrm{Zr}$ (40). After aging, only the solute-enriched dendritic cells contain precipitates, as described subsequently.

\section{B. Age Hardening}

Figure 3 displays the evolution of microhardness of the Al-Ti and Al-Zr alloys upon isothermal aging at $375^{\circ} \mathrm{C}$ or $425^{\circ} \mathrm{C}$. Each data point represents a minimum of 20 measurements, with the standard deviation of these measurements indicated by the error bars. At both temperatures, the Al-Ti alloys exhibit a negligible age hardening response after extended aging times up to 3,200 hours (19 weeks). This lack of strengthening contrasts with the significant precipitation hardening response of the Al-Zr alloy, which commences at times as short as 0.1 hours ( 6 minutes) at $425^{\circ} \mathrm{C}$ and achieves peak strength within 25 hours at both $375^{\circ} \mathrm{C}$ and $425^{\circ} \mathrm{C}$. As described subsequently, the pronounced strengthening is due to precipitation of small $(<10 \mathrm{~nm})$ coherent $\mathrm{Al}_{3} \mathrm{Zr} \quad\left(\mathrm{Ll}_{2}\right)$ precipitates; no evidence for precipitation of a similar $\mathrm{Al}_{3} \mathrm{Ti}$ phase is observed. The as-cast hardness values of $\mathrm{Al}-0.22 \mathrm{Ti}$ and $\mathrm{Al}-0.19 \mathrm{Zr}$ are both $242 \mathrm{MPa}$, approximately $20 \mathrm{MPa}$ greater than that of A1-0.18Ti. This moderate strength increase is probably attributable to solid solution strengthening from dissolved $\mathrm{Ti}$ or $\mathrm{Zr}$ in the as-cast alloys. ${ }^{[48,49]}$ While there is a refinement in the as-cast grain size with increasing solute concentration (Figure 1), Hall-Petch strengthening is not applicable because the scale of the microhardness

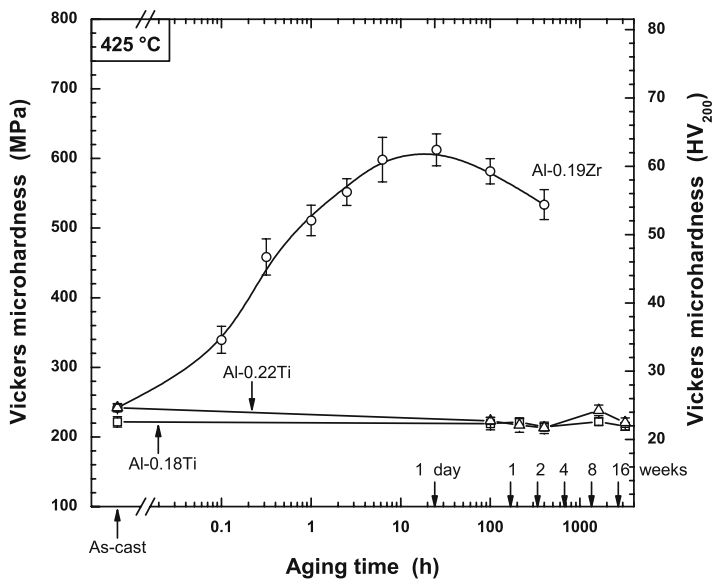

(b)

Fig. 3-Plot of Vickers microhardness $v s$ aging time at (a) $375^{\circ} \mathrm{C}$ and $\left(\right.$ b) $425{ }^{\circ} \mathrm{C}$, for Al-0.18Ti, Al-0.22Ti, and Al-0.19Zr. 
indent (approximately $125 \mu \mathrm{m}$ across) is small as compared with the grain size.

\section{Electron Microscopy}

The origin of the precipitation-hardening response indicated in Figure 3 was investigated directly for Al-0.22Ti and Al-0.19Zr using SEM (Figure 4). The dendritic distribution of solute species formed during solidification in both alloys is revealed by preferential etching of the foil's surface during electropolishing. Figure 4(a) shows the as-cast structure for Al-0.22Ti, where the relief contrast around the dendrite arms is due to variations in solute concentration in solid solution between the dendritic and interdendritic regions of the alloy. The centers of the dendrites are enriched in solute ${ }^{[36,50-52]}$ and are apparently more resistant to electropolishing. Ryum $\left.{ }^{[53}\right]$ observed similar resistance to electropolishing in the dendritic cells of as-cast specimens of Al-Hf alloys. Figure 4(b) shows the same Al-0.22Ti alloy after aging for 1600 hours at $425^{\circ} \mathrm{C}$. The dendritic cells are delineated as previously, but no evidence for precipitation of $\mathrm{Al}_{3} \mathrm{Ti}$ within the supersaturated cells is observed, consistent also with the negligible age hardening of the Al-Ti alloys demonstrated in Figure 3. Examination of the same specimen by TEM, both in real space (strain contrast) and reciprocal space (selected area electron diffraction), also provided no evidence for $\mathrm{Al}_{3} \mathrm{Ti}$ precipitates or any other precipitated phase.

Figures 4(c) and 4(d) show SEM micrographs for Al-0.19Zr aged 400 hours at $425^{\circ} \mathrm{C}$. As with the Ticontaining alloys, dendrites are clearly delineated from the electropolishing process. Unlike the Al-Ti alloys, however, the solute-rich dendrites decompose during aging to form regions with a high number density of

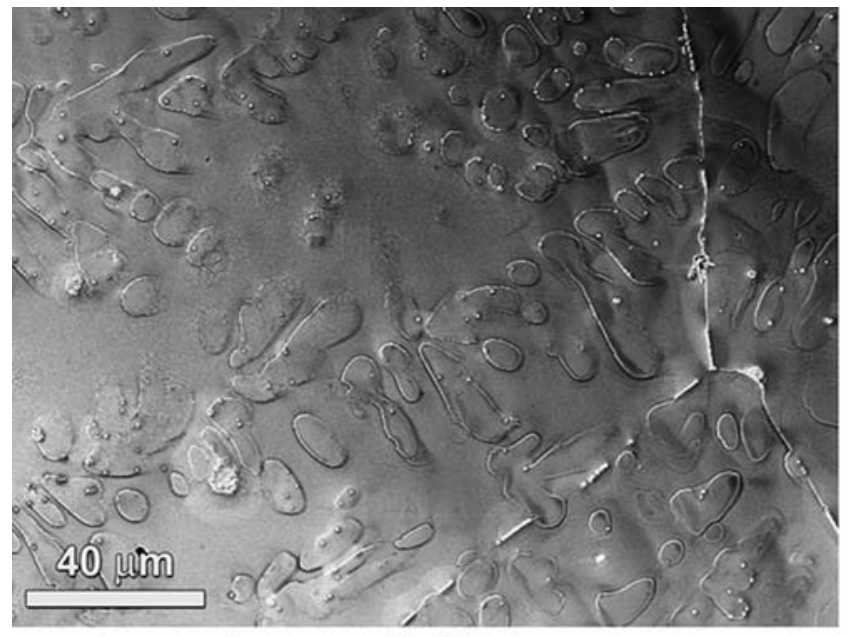

(a)

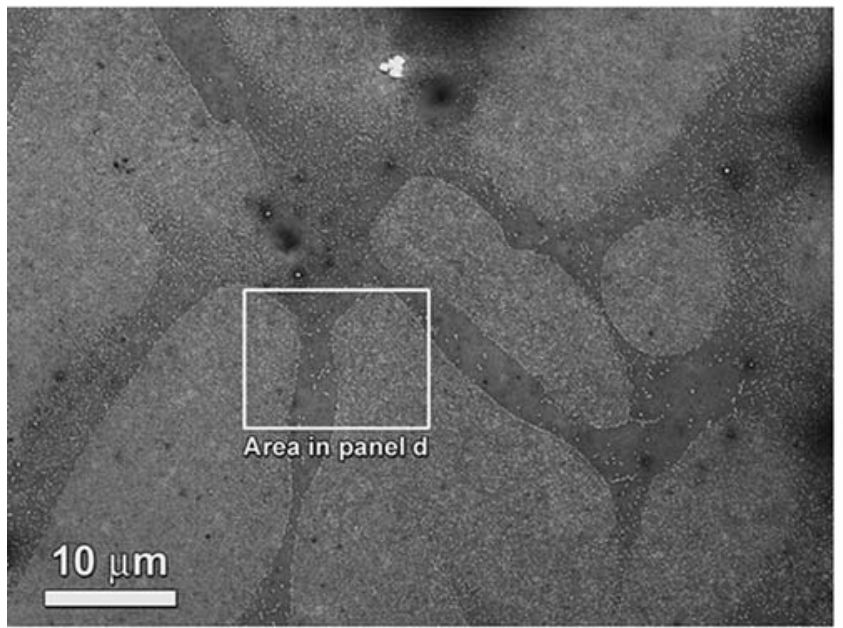

(c)

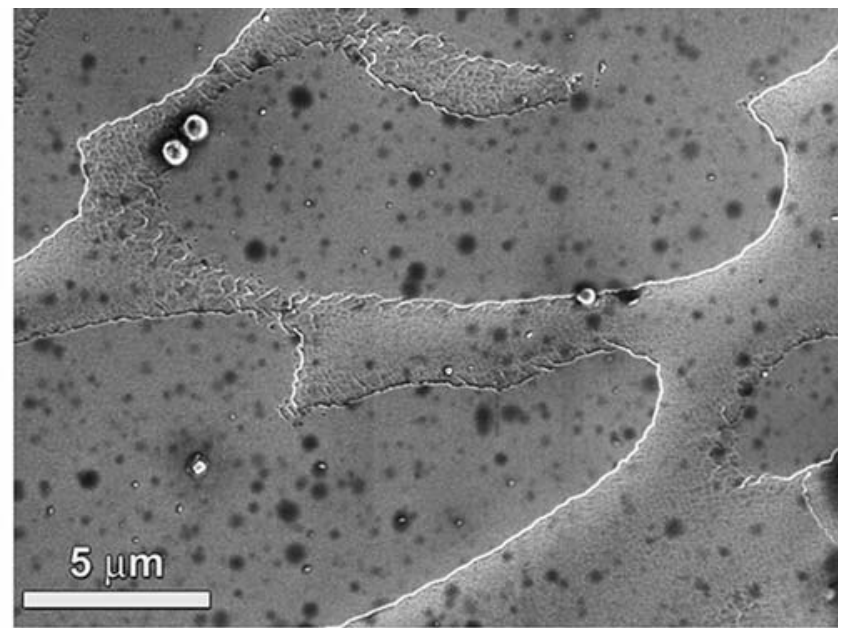

(b)

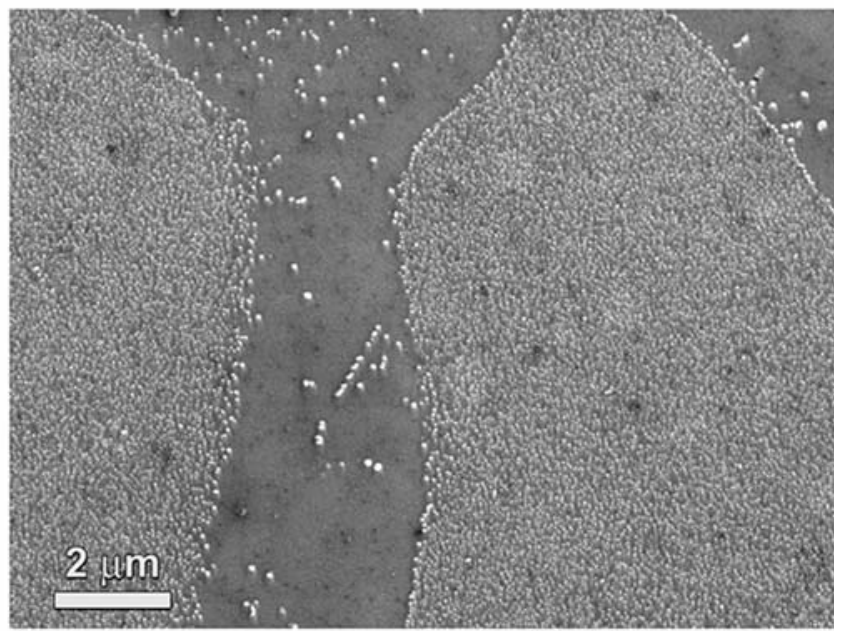

(d)

Fig. 4 - SEM micrographs of electropolished TEM foils. (a) As-cast Al-0.22Ti, showing preferential etching around the solute-enriched dendrites. (b) Al-0.22 Ti aged at $425{ }^{\circ} \mathrm{C}$ for $1600 \mathrm{~h}$, showing no evidence of precipitation of $\mathrm{Al}_{3} \mathrm{Ti}$ within the solute-enriched dendrites (black spots are pits from electropolishing). (c) Al-0.19Zr aged at $425^{\circ} \mathrm{C}$ for $400 \mathrm{~h}$, showing dendritic distributions of solute similar to panel (a). (d) Magnified view of panel (c), showing $\mathrm{Al}_{3} \mathrm{Zr}$ dendritic regions with a high number density of small precipitates and interdendritic channels with isolated heterogeneously-nucleated precipitates of larger size. 


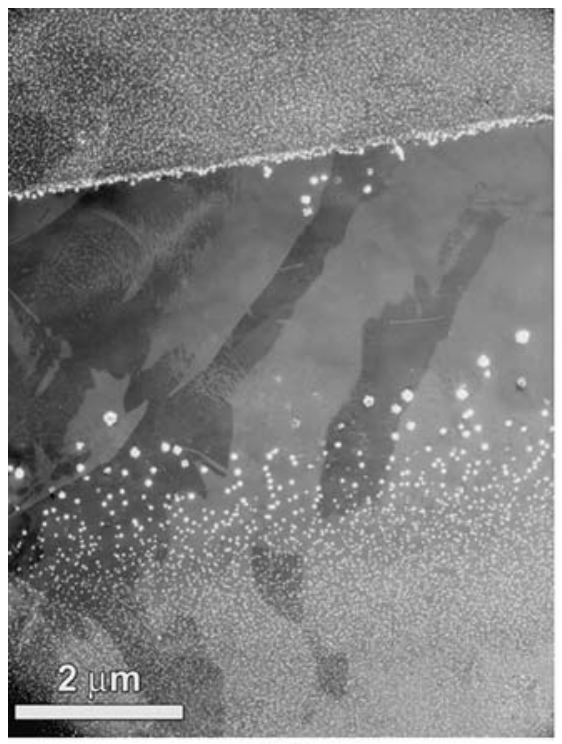

(a)

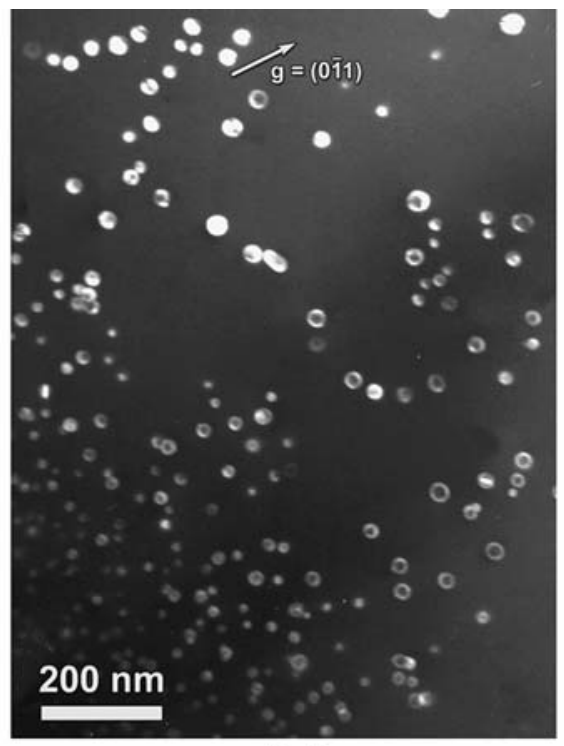

(b)

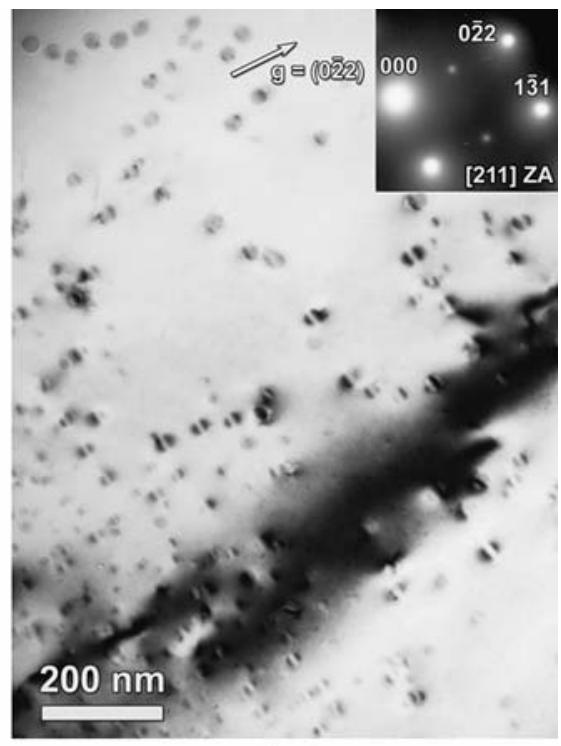

(c)

Fig. 5-TEM micrographs of Al-0.19Zr aged at $425^{\circ} \mathrm{C}$ for 400 h. (a) Precipitate-rich dendritic regions separated by a precipitate-free interdendritic channel similar to those in Figs. 4(c) and 4(d). (b) Magnified view of $\mathrm{Al}_{3} \mathrm{Zr}\left(\mathrm{Ll}_{2}\right)$ precipitates near the dendrite periphery. (c) Complementary bright-field image of the region in $(b)$. The strain fields surrounding the precipitates exhibit distinct lines of no-contrast normal to the diffraction vector, $\mathbf{g}$, indicating that the precipitates are coherent with the $\alpha$-Al solid solution.

homogeneously distributed, nanometer-scale $\mathrm{Al}_{3} \mathrm{Zr}$ precipitates. Figure 5 shows superlattice dark-field TEM micrographs of the same Al-0.19Zr specimen, exhibiting again precipitate-rich and precipitate-free regions associated with the initial dendritic $\mathrm{Zr}$ distribution (Figure 5(a)). Within the center of the dendrites, where the solute supersaturation is largest, the small $(<R>=6.7 \pm 1.7 \mathrm{~nm}) \mathrm{Al}_{3} \mathrm{Zr}$ precipitates have the metastable cubic $\mathrm{Ll}_{2}$ structure and are homogeneously distributed in high number densities. The supersaturation decays with lateral position from the dendrite centers and, correspondingly, the precipitates become progressively larger and occur in smaller number densities (Figures 5(a) and (b)). Figure 5(c) is a complementary bright-field micrograph to that of Figure 5(b), recorded under two-beam conditions. The characteristic Ashby-Brown ${ }^{[54]}$ strain contrast surrounding the $\mathrm{Al}_{3} \mathrm{Zr}\left(\mathrm{Ll}_{2}\right)$ precipitates indicates that they are coherent with $\alpha$-Al. It is the small, coherent, high number density $\mathrm{Al}_{3} \mathrm{Zr}\left(\mathrm{Ll}_{2}\right)$ precipitates within the dendrites that are responsible for the marked precipitation-hardening response of $\mathrm{Al}-0.19 \mathrm{Zr}$ presented in Figure 3.

\section{Electrical Conductivity}

The electrical conductivity of a disordered binary substitutional alloy is a parabolic function of the absolute solute concentration ${ }^{[55]}$ and is therefore a sensitive means of monitoring the decomposition of a supersaturated solid solution during aging. Electrical conductivity measurements were performed on both Al-Ti alloys (Al-0.18Ti and Al-0.22Ti) for extended aging times up to 1600 hours at $425{ }^{\circ} \mathrm{C}$. No detectable change in conductivity was observed, indicating that solute atoms remained dissolved in supersaturated solid solution and did not precipitate as $\mathrm{Al}_{3} \mathrm{Ti}$, corroborating the lack of precipitation observed by hardness and electron microscopy.

There was insufficient material to perform electrical conductivity measurements for the present $\mathrm{Al}-0.19 \mathrm{Zr}$ alloy. In a subsequent article, ${ }^{[35]}$ however, we monitor the decomposition of more-dilute Al-0.1 at. pet $\mathrm{Zr}$ alloys during isochronal aging, during which a significant increase in electrical conductivity is observed to accompany precipitation of $\mathrm{Al}_{3} \mathrm{Zr}$. Moreover, Royset and Ryum $^{[56]}$ recently monitored in detail the decomposition kinetics of dilute Al-0.12 at. pct Sc alloys using a similar eddy current apparatus, indicating that the technique is sensitive enough to detect precipitation of $\mathrm{Al}_{3} \mathrm{M}$ in dilute alloys.

\section{DISCUSSION}

The hardness data in Figure 3 demonstrate that the Al-0.19Zr alloy exhibits pronounced precipitation hardening at $375^{\circ} \mathrm{C}$ and $425^{\circ} \mathrm{C}$, unlike the $\mathrm{Al}-\mathrm{Ti}$ alloys with similar solute concentrations. The strong age hardening response of the $\mathrm{Zr}$-containing alloy is due to the precipitation of small $(<10 \mathrm{~nm})$ coherent $\mathrm{Al}_{3} \mathrm{Zr}\left(\mathrm{L1}_{2}\right)$ precipitates, shown by SEM (Figures 4(c) and 4(d)) and TEM (Figure 5). No evidence for precipitation of a similar $\mathrm{Al}_{3} \mathrm{Ti}$ phase is observed in the Al-Ti alloys by SEM or TEM. Moreover, there is no appreciable change in electrical conductivity after aging Al-0.18Ti or $\mathrm{Al}-0.22 \mathrm{Ti}$ at $425^{\circ} \mathrm{C}$ for 1600 hours, which indicates that the Ti concentration in $\alpha$-Al solid solution is unchanged, confirming the lack of precipitation of $\mathrm{Al}_{3} \mathrm{Ti}$. 


\section{A. Diffusion Kinetics}

The measured tracer diffusivity of $\mathrm{Ti}$ in $\alpha$ - $\mathrm{Al}$ is smaller than that of $\mathrm{Zr}$ in $\alpha$-Al at the aging temperatures employed, and it is conceivable that sluggish diffusion might account for the lack of $\mathrm{Al}_{3} \mathrm{Ti}$ precipitation. The diffusivities, $D$, of $\mathrm{Ti}$ or $\mathrm{Zr}$ in $\alpha$-Al are given by an Arrhenius relationship:

$$
D=D_{0} \cdot \exp \left(-\frac{Q}{\mathrm{R}_{\mathrm{g}} T}\right)
$$

where $\mathrm{R}_{\mathrm{g}}$ is the ideal gas constant, $T$ is the absolute temperature, $Q$ is the activation enthalpy for solute diffusion, and $D_{0}$ is the pre-exponential factor. With values $Q=260$ and $242 \mathrm{~kJ} \mathrm{~mol}^{-1}$ and $D_{0}=1.12 \times 10^{-1}$ and $7.28 \times 10^{-2} \mathrm{~m}^{2} \mathrm{~s}^{-1}$ for $\mathrm{Ti}$ and $\mathrm{Zr}$, respectively, ${ }^{[1]}$ the diffusivity of Ti at $425^{\circ} \mathrm{C}\left(3.90 \times 10^{-21} \mathrm{~m}^{2} \mathrm{~s}^{-1}\right)$ is comparable to that of $\mathrm{Zr}$ at $375^{\circ} \mathrm{C}\left(2.26 \times 10^{-21} \mathrm{~m}^{2} \mathrm{~s}^{-1}\right)$. The hardness curve in Figure 3(a) demonstrates that the Al-Zr binary alloy reaches near-peak hardness by 6.25 hours of aging at $375{ }^{\circ} \mathrm{C}$, which corresponds to a root-mean-squared (RMS) diffusion distance, $\sqrt{4 D t}$ (where $t$ is the aging time), of $14 \mathrm{~nm}$ for $\mathrm{Zr}$ atoms. For the slower-diffusing Ti atoms, a similar RMS diffusion distance can be achieved after 115 hours at $375{ }^{\circ} \mathrm{C}$ or 4 hours at $425{ }^{\circ} \mathrm{C}$, indicating that $\mathrm{Ti}$ atoms diffuse fast enough to support the nucleation and growth of $\mathrm{Al}_{3} \mathrm{Ti}$ precipitates. Atom-probe tomography studies on Al-Sc-Ti alloys aged at $300{ }^{\circ} \mathrm{C}{ }^{[57]}$ and $\mathrm{Al}-\mathrm{Zr}$ - $\mathrm{Ti}$ alloys aged at $375^{\circ} \mathrm{C}$ or $425^{\circ} \mathrm{C}^{[58]}$ demonstrate that Ti segregates to the $\mathrm{Al}_{3}\left(\mathrm{Sc}_{1-x} \mathrm{Ti}_{x}\right)$ and $\mathrm{Al}_{3}\left(\mathrm{Zr}_{1-x} \mathrm{Ti}_{x}\right)$ precipitates, further evidence that the limited mobility of Ti is not the limiting factor explaining the lack of $\mathrm{Al}_{3}$ Ti precipitation.

\section{B. Classical Nucleation Theory}

The inability to nucleate $\mathrm{Al}_{3} \mathrm{Ti}$ is a result of an insufficient supersaturation of $\mathrm{Ti}$ in solid solution following conventional solidification. Figures 6 and 7 display dilute equilibrium binary phase diagrams for the $\mathrm{Al}-\mathrm{Ti}$ and $\mathrm{Al}-\mathrm{Zr}$ systems based on experimental data. From a casting standpoint, a suitable alloying element with Al should produce a low liquidus temperature or, equivalently, exhibit high solubility in the liquid. This liquidus criterion minimizes, for a given alloy composition, the temperature required to form a single-phase melt and also reduces the tendency for primary phase precipitation during solidification. ${ }^{[1]}$ For precipitation strengthening, limited solid solubility is required to maximize the chemical driving force for nucleation as well as the volume fraction of the precipitated phase. As shown in Figures 6 and 7, the disparity in the liquid and solid solubilities of $\mathrm{Ti}$ in $\alpha-\mathrm{Al}$ is much greater than that of $\mathrm{Zr}$.

The equilibrium phase boundaries in Figures 6 and 7 correspond to the tetragonal-structured trialuminides: $\mathrm{D}_{22}$ for $\mathrm{Al}_{3} \mathrm{Ti}^{\left[{ }^{[59]}\right.}$ and $\mathrm{D}_{23}$ for $\mathrm{Al}_{3} \mathrm{Zr}{ }^{[60]}$ The solubility limits of $\mathrm{Ti}$ and $\mathrm{Zr}$ in $\alpha-\mathrm{Al}$, in equilibrium with their respective metastable $\mathrm{Ll}_{2}$ structure $\mathrm{Al}_{3} \mathrm{M}$ trialuminides, have been evaluated employing $a b$ initio calculations by Liu et al. ${ }^{[61,62]}$ who show that the ratio of the solid solubilities of the stable and metastable phases may be written as

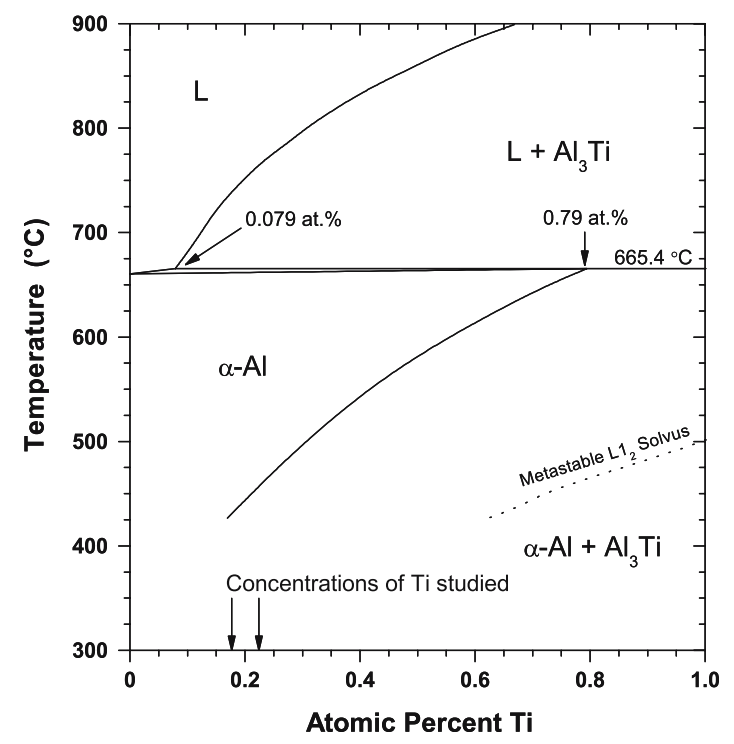

Fig. 6-Equilibrium Al-rich Al-Ti binary phase diagram (adapted from Murray $\left.{ }^{[59]}\right)$ with metastable $\mathrm{Al}_{3} \mathrm{Ti}\left(\mathrm{Ll}_{2}\right)$ solvus calculated by Liu et al. ${ }^{[61,62]}$

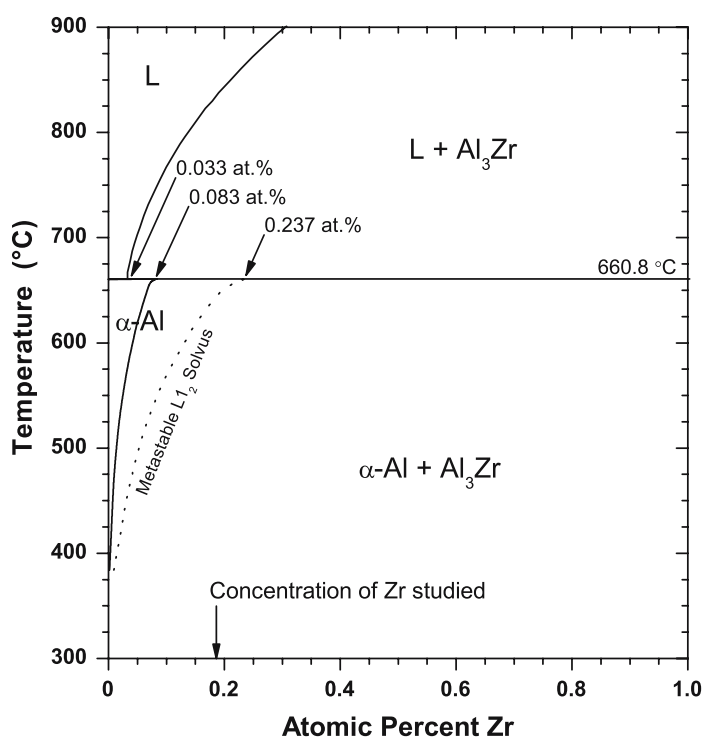

Fig. 7-Equilibrium Al-rich Al-Zr binary phase diagram (adapted from Murray $\left.{ }^{[60]}\right)$ with metastable $\mathrm{Al}_{3} \mathrm{Zr}\left(\mathrm{Ll}_{2}\right)$ solvus calculated by Liu et al..$^{[61,62]}$

$$
\begin{aligned}
& C_{\text {ratio }}^{\mathrm{Al}_{3} \mathrm{Ti}}=0.816 \cdot \exp (1068 / T) \\
& C_{\text {ratio }}^{\mathrm{Al}_{3} \mathrm{Zr}}=0.710 \cdot \exp (1300 / T)
\end{aligned}
$$

where $C_{\text {ratio }}^{\mathrm{Al} 3 \mathrm{Ti}}$ and $C_{\text {ratio }}^{\mathrm{Al}_{3} \mathrm{Zr}}$ are the ratios of the solid solubility of $\mathrm{Al}_{3} \mathrm{Ti}\left(\mathrm{Ll}_{2}\right)$ and $\mathrm{Al}_{3} \mathrm{Zr}\left(\mathrm{Ll}_{2}\right)$ with their respective equilibrium $\left(\mathrm{D}_{22}\right.$ or $\left.\mathrm{DO}_{23}\right)$ solvus curves, and $T$ is the absolute temperature. Using the equilibrium phase boundaries in Figures 6 and 7 as an accurate reference state, metastable $\mathrm{L}_{2}$ solvus boundaries are calculated using Eqs. [2] and are indicated by the dotted lines in Figures 6 and 7. 
According to classical nucleation theory, ${ }^{[63-67]}$ the steady-state nucleation current (nucleation rate per unit volume) is given by

$$
J \propto \exp \left(-\frac{\Delta F^{*}}{\mathrm{R}_{\mathrm{g}} T}\right) \exp \left(-\frac{Q}{\mathrm{R}_{\mathrm{g}} T}\right)
$$

where $\Delta F^{*}$ is the net reversible work required for the formation of a critical nucleus, which is given by

$$
\Delta F^{*}=\frac{16 \pi \sigma^{3}}{3\left(\Delta F_{c h}-\Delta F_{e l}\right)^{2}}
$$

The steady-state nucleation current, Eq. [3], is thus a function of the interfacial-free energy, $\sigma$; the chemical driving force, $\Delta F_{c h}$; the reduction of $\Delta F_{c h}$ by the elastic strain energy, $\Delta F_{e l}$; and the activation enthalpy for diffusion, $Q$, for diffusion of the solute. As discussed in Sections 1 through 4, the latter three parameters hinder the nucleation of $\mathrm{Al}_{3}$ Ti compared with $\mathrm{Al}_{3} \mathrm{Zr}$.

1. Chemical driving force, $\Delta F_{c h}$, for nucleation of $A l_{3} M$

The metastable $\mathrm{L}_{2}$ solvus boundaries in Figures 6 and 7 demonstrate that the solid solubility of $\mathrm{Ti}$ in $\alpha$-Al is significantly greater than that of $\mathrm{Zr}$, which dictates the chemical driving force for homogenous nucleation of metastable $\mathrm{Ll}_{2} \mathrm{Al}_{3} \mathrm{M}(\mathrm{M}=\mathrm{Ti}$ or $\mathrm{Zr})$. Assuming ideal solution behavior (valid for the dilute concentrations discussed), this driving force is proportional to the natural logarithm of the supersaturation ratio, $C_{0} / C_{\alpha}$, where $C_{0}$ is the concentration (atomic fraction) of $\mathrm{M}$ dissolved in solid solution and $C_{\alpha}$ is the solid solubility of $\mathrm{M}$ in $\alpha$-Al given by Eq. [2]. Following Doherty, ${ }^{[65]}$ the chemical driving force per unit volume driving precipitation of the ordered $\mathrm{Al}_{3} \mathrm{M}$ phase may be estimated as

$$
\Delta F_{c h}=\frac{\mathrm{R}_{\mathrm{g}} T}{V_{\mathrm{Al}_{3} \mathrm{M}}}\left(\frac{C_{\mathrm{Al}_{3} \mathrm{M}}-C_{\alpha}}{1-C_{\alpha}}\right) \ln \frac{C_{0}}{C_{\alpha}}
$$

where $C_{\mathrm{Al}_{3} \mathrm{M}}=0.25$ is the atomic fraction of solute in the ordered trialuminide, and $V_{\mathrm{Al}_{3} \mathrm{M}}=\mathrm{N}_{\mathrm{a}}\left(a_{\mathrm{Al}_{3} \mathrm{M}}\right)^{3} / 4$ is the molar volume of the precipitated phase $\left(\mathrm{N}_{\mathrm{a}}\right.$ is Avogadro's number and $a_{\mathrm{Al}_{3} \mathrm{M}}=0.3967$ and $0.408 \mathrm{~nm}$ for $\mathrm{Al}_{3} \mathrm{Ti}\left(\mathrm{Ll}_{2}\right)$ and $\mathrm{Al}_{3} \mathrm{Zr}\left(\mathrm{Ll}_{2}\right)$, respectively $\left.{ }^{[1]}\right)$.

Figures 6 and 7 indicate that, for a given solute concentration $\left(C_{0}\right)$, the supersaturation driving precipitation of $\mathrm{Al}_{3} \mathrm{Zr}$ is significantly greater than that for $\mathrm{Al}_{3} \mathrm{Ti}$, which partially explains the absence of precipitation of $\mathrm{Al}_{3}$ Ti because of the reduced supersaturation ratio $C_{0} / C_{\alpha}$ in Eq. [5]. The solute concentration $C_{0}$, however, is not constant throughout the alloys because of the segregation visible in the SEM micrographs of Figure 4. For both $\mathrm{Al}-\mathrm{Ti}$ and $\mathrm{Al}-\mathrm{Zr}$, the dendrites are supersaturated with respect to the overall bulk alloy composition, $C_{0}$, and so in both cases the local supersaturation of solute in the dendrites is greater than the bulk compositions indicated in Table I and Figures 6 and 7 .

The degree of this segregation was not measured directly (e.g., by electron microprobe analysis (EPMA)) but may be estimated from the equilibrium solid-liquid partition coefficient, $k_{0}$, that quantifies the difference in the compositions of the solid and liquid phases in local equilibrium during solidification. ${ }^{[68-70]}$ Making the standard assumption that both the liquidus and solidus boundaries are straight lines, $k_{0}$ may be expressed as the ratio of the solid and liquid compositions at the peritectic temperature, $k_{0}=C_{S} / C_{L}$. From Figures 6 and $7, k_{0}=10$ for $\mathrm{Ti}$, and $k_{0}=2.5$ for $\mathrm{Zr}$; therefore, the first solid to form is predicted to be enriched by a factor of 10 and 2.5 for $\mathrm{Ti}$ and $\mathrm{Zr}$, respectively. This is in reasonable agreement with the results of Bolling and colleagues, ${ }^{[36,50]}$ who measured, using EPMA, the concentration of Ti across the dendritic cells in Al-Ti alloys containing up to 0.28 at. pct $\mathrm{Ti}$ and observed a five- to sixfold enrichment in Ti at the dendrite centers. Setiukov and Fridlyander ${ }^{[52]}$ similarly observed that the $\mathrm{Ti}$ concentration in the central zones of the dendritic cells exceeded its average value by 6 to 8 times in alloys containing 0.02 to 0.17 at. pet Ti. All present Al-Ti and $\mathrm{Al}-\mathrm{Zr}$ alloys are therefore locally supersaturated well beyond their respective equilibrium solubilities of solute, and so an insufficient supersaturation of solute, $\Delta F_{c h}$, alone cannot account for the absence of $\mathrm{Al}_{3} \mathrm{Ti}$ precipitates. As indicated in Eq. [4], the influence of elastic strain energy, $\Delta F_{e l}$, must also be considered because this reduces the net driving force for nucleation.

\section{Reduction of the driving force by the elastic strain energy, $\Delta F_{e l}$}

Solid-state reactions involve strain energy because precipitating a second phase, which is fully or partially coherent with the matrix, requires the straining of the lattices in both the matrix and precipitated phases. This elastic strain energy, $\Delta F_{e l}$, diminishes the net driving force, Eq. [4], and hence the rate of nucleation, Eq. [3]. Considering only dilatational strains and assuming elastic isotropy, the strain energy per unit volume for a coherent inclusion is given by ${ }^{[64,67]}$

$$
\Delta F_{e l}=2 \mu\left(\frac{1+v}{1-v}\right) \delta^{2}
$$

where $\mu=25.4 \mathrm{GPa}^{[71]}$ and $v=0.345^{[72]}$ are the shear modulus and Poisson's ratio of $\mathrm{Al}$ at room temperature. The average lattice parameter mismatches at room temperature, $\delta$, of both the tetragonal $\left(\mathrm{D}_{22}\right.$ or $\left.\mathrm{D}_{23}\right)$ and metastable cubic $\left(\mathrm{L1}_{2}\right)$ phases are significantly greater for $\mathrm{Al}_{3} \mathrm{Ti}\left(\delta=2.04\right.$ pct and 5.36 pct for $\mathrm{Ll}_{2}$ and $\mathrm{D}_{22}$, respectively) than for $\mathrm{Al}_{3} \mathrm{Zr}(\delta=0.75 \mathrm{pct}$ and 2.89 pct for $\mathrm{L}_{2}$ and $\mathrm{D}_{23}$, respectively). ${ }^{[1]}$ Thus, the elastic strain energy preventing nucleation of $\mathrm{Al}_{3} \mathrm{Ti}$ $\left(\mathrm{L1}_{2}\right)$ is more than 7 times greater than that of $\mathrm{Al}_{3} \mathrm{Zr}$ $\left(\mathrm{L1}_{2}\right)$. The lattice parameter mismatch $\delta$, and thus the elastic strain energy is, however, expected to decrease somewhat at higher temperatures, owing to differences in thermal expansion between the $\alpha$-Al matrix and the $\mathrm{Al}_{3} \mathrm{M}$ precipitates. ${ }^{[73,74]}$ Similarly, the shear modulus at higher temperature is somewhat reduced.

3. Critical solute concentration, $C_{0}$, to overcome $\Delta F_{e l}$ Compared with $\mathrm{Al}_{3} \mathrm{Zr}\left(\mathrm{Ll}_{2}\right)$, nucleation of $\mathrm{Al}_{3} \mathrm{Ti}\left(\mathrm{Ll}_{2}\right)$ is hindered by the following: (1) a reduced chemical driving force $\left(\Delta F_{c h}\right)$ for a given $C_{0}$; and (2) a greater 


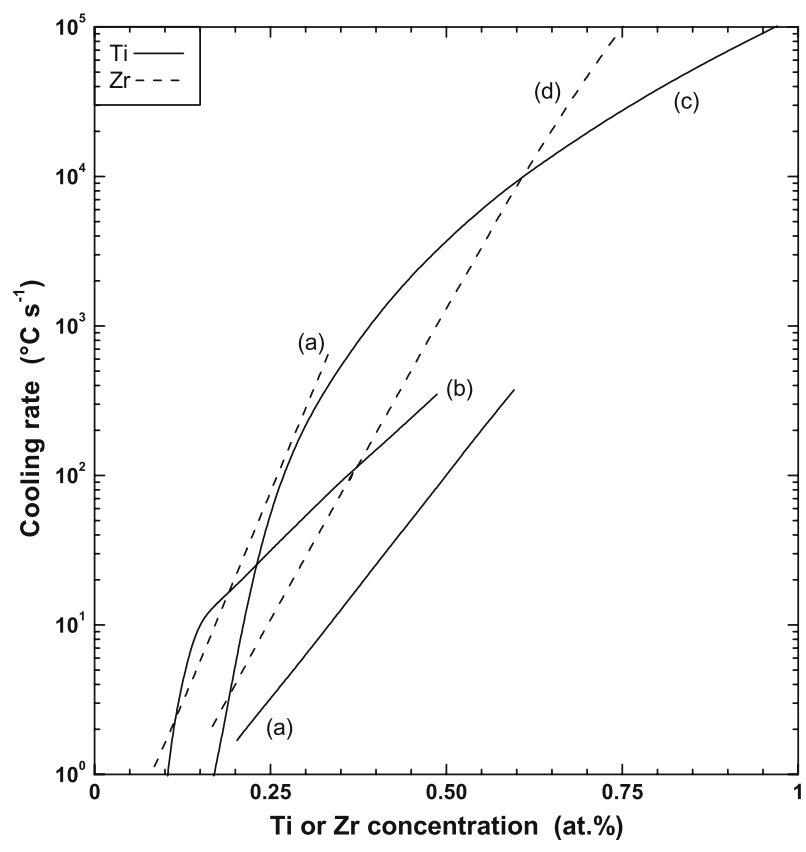

Fig. 8-Critical cooling rate for suppressing primary $\mathrm{Al}_{3} \mathrm{Ti}$ (solid lines) or $\mathrm{Al}_{3} \mathrm{Zr}$ (dashed lines) and achieving supersaturated $\alpha$-Al solid solution, as reported by $(a)$ Ohashi and Ichikawa, ${ }^{[19]}$ (b) Kerr et al. ${ }^{[36]}\left(\right.$ c) Hori et al., ${ }^{[75,76]}$ and (d) Hori et al. ${ }^{[24]}$

elastic strain energy opposing nucleation $\left(\Delta F_{e l}\right)$. To explain why nucleation of $\mathrm{Al}_{3} \mathrm{Zr}\left(\mathrm{Ll}_{2}\right)$ is observed and that of $\mathrm{Al}_{3} \mathrm{Ti}\left(\mathrm{Ll}_{2}\right)$ is not, consider the relative magnitudes of $\Delta F_{c h}$ and $\Delta F_{e l}$ entering Eq. [4] for both systems. The chemical driving force, $\Delta F_{c h}$ (Eq. [5]), is calculated substituting $C_{\alpha}=0.0063$ for $\mathrm{Al}_{3} \mathrm{Ti}\left(\mathrm{Ll}_{2}\right)$ and $C_{\alpha}=$ 0.0002 for $\mathrm{Al}_{3} \mathrm{Zr}\left(\mathrm{Ll}_{2}\right)$, using Eq. [2] at $425{ }^{\circ} \mathrm{C}$. Substituting the appropriate values for $V_{\mathrm{Al}_{3} \mathrm{M}}, \Delta F_{c h}=151.4 \mathrm{ln}$ $\left(158.7 C_{0}\right)$ for $\mathrm{Al}_{3} \mathrm{Ti}\left(\mathrm{Ll}_{2}\right)$, and $\Delta F_{c h}=141.9 \ln \left(5000 C_{0}\right)$ for $\mathrm{Al}_{3} \mathrm{Zr}\left(\mathrm{Ll}_{2}\right)$. The elastic strain energy, $\Delta F_{\mathrm{el}}(\mathrm{Eq}$. [6]), is $45 \mathrm{MJ} \mathrm{mol}^{-1}$ and $6 \mathrm{MJ} \mathrm{mol}^{-1}$ for $\mathrm{Al}_{3} \mathrm{Ti}\left(\mathrm{Ll}_{2}\right)$ and $\mathrm{Al}_{3} \mathrm{Zr}$ $\left(\mathrm{Ll}_{2}\right)$, respectively. Equating $\Delta F_{c h}$ and $\Delta F_{e l}$ gives a critical solute concentration necessary to overcome the elastic strain energy barrier associated with precipitate nucleation. For Al-Ti alloys, the critical value of $C_{0}$ is 0.84 at. pet $\mathrm{Ti}$, and for $\mathrm{Al}-\mathrm{Zr}$, it is 0.021 at. pet $\mathrm{Zr}$.

Table I indicates that the bulk compositions of both Al-Ti alloys studied are less than the critical threshold of 0.84 at. pet $\mathrm{Ti}$, whereas $\mathrm{Al}-0.19 \mathrm{Zr}$ is supersaturated well beyond 0.021 at. pct $\mathrm{Zr}$, thus explaining the observed precipitation of $\mathrm{Al}_{3} \mathrm{Zr}\left(\mathrm{Ll}_{2}\right)$ and the lack thereof for $\mathrm{Al}_{3}$ Ti. This explanation is not strictly complete because, as discussed, the alloys are segregated and hence locally supersaturated beyond the bulk compositions in Table I. Nevertheless, it is the combination of a small chemical driving force, $\Delta F_{c h}$, coupled with a large elastic strain energy barrier, $\Delta F_{e l}$, in the Al-Ti system, as compared with the $\mathrm{Al}-\mathrm{Zr}$ system, that explains their disparate precipitation behavior.

\section{Activation enthalpy for solute diffusion, $Q$}

Equation [3] indicates that the nucleation current is strongly dependent on temperature. The solute supersaturation (and, correspondingly, $\Delta F_{c h}$ ) increases with decreasing temperature (Eq. [2]), while the solute diffusivity $D$ decreases exponentially (Eq. [1]). These competing influences result in an intermediate temperature for optimum nucleation kinetics. ${ }^{[6]}$ As discussed in Section IV-A, the activation enthalpy for solute diffusion, $Q$, for Ti in $\alpha-\mathrm{Al}\left(260 \mathrm{~kJ} \mathrm{~mol}^{-1}\right)$ is greater than that of $\mathrm{Zr}\left(242 \mathrm{~kJ} \mathrm{~mol}^{-1}\right)$, which increases the temperature for maximum nucleation current for $\mathrm{Al}_{3} \mathrm{Ti}$. As discussed, the value of $\Delta F_{c h}$ driving precipitation of $\mathrm{Al}_{3} \mathrm{Ti}$ is significantly less than that for $\mathrm{Al}_{3} \mathrm{Zr}$ for a given $C_{0}$ (Figures 6 and 7). This reduced $\Delta F_{c h}$ is exacerbated by the higher $Q$ for $\mathrm{Ti}$ diffusion because at the temperatures where $\mathrm{Ti}$ is mobile, the supersaturation is not large enough to effect nucleation of $\mathrm{Al}_{3} \mathrm{Ti}$.

\section{Limitations on Increasing the Solute Concentration}

The discussion in Section IV-B indicates that an increased concentration of $\mathrm{Ti}\left(C_{0}\right)$ beyond those we studied is required for precipitation of $\mathrm{Al}_{3} \mathrm{Ti}$. This, however, is not possible under conventional casting conditions. As demonstrated in Figure 1, the marked grain refinement observed with increasing Ti concentration is due to primary precipitation of $\mathrm{Al}_{3} \mathrm{Ti}$ in the melt, and increasing the Ti concentration does not increase the amount of Ti retained in $\alpha$-Al solid solution. The inter-relationships among solidification rates, solute concentrations, and solidified microstructures of the $\mathrm{Al}-\mathrm{Ti}$ and Al-Zr binary systems have been the subject of prior studies, ${ }^{[19,24,36,75,76]}$ which are summarized in Figure 8. These curves show the measured solidification rate, as a function of solute concentration, necessary to suppress primary precipitation of $\mathrm{Al}_{3} \mathrm{Ti}$ or $\mathrm{Al}_{3} \mathrm{Zr}$, thereby obtaining supersaturated $\alpha$-Al solid solution. Figure 8 indicates that to achieve a concentration of 0.84 at. pct Ti supersaturated in an homogenous $\alpha$-Al solid solution, required to just offset the elastic strain energy associated with nucleation of $\mathrm{Al}_{3} \mathrm{Ti}\left(\mathrm{Ll}_{2}\right)$, cooling rates of nearly $5 \times 10^{4}{ }^{\circ} \mathrm{C} \mathrm{s}^{-1}$ (based on the data of Hori et al. ${ }^{[75,76]}$ ) are required. To achieve a greater driving force for nucleation, still higher cooling rates are required. Nucleation of $\mathrm{Al}_{3} \mathrm{Zr}\left(\mathrm{Ll}_{2}\right)$ requires a small supersaturation to overcome the elastic strain energy barrier, and the critical composition of 0.021 at. pct $\mathrm{Zr}$ is readily achieved for even the slowest cooling rates in Figure 8.

\section{Comparison with Previous Studies}

In contrast to the closely related $\mathrm{Al}-\mathrm{Zr}$ and $\mathrm{Al}-\mathrm{Hf}$ systems, the precipitation behavior of $\mathrm{Al}_{3} \mathrm{Ti}$ in $\mathrm{Al}-\mathrm{Ti}$ alloys has been debated in the scientific literature. As with $\mathrm{Al}-\mathrm{Zr}$ and $\mathrm{Al}-\mathrm{Hf}$ alloys, the decomposition sequence of supersaturated Al-Ti solid solutions has been reported to occur first by the precipitation of a metastable $\mathrm{Al}_{3} \mathrm{Ti}\left(\mathrm{Ll}_{2}\right)$ phase, which then transforms to the equilibrium tetragonal $\left(\mathrm{D}_{22}\right)$ structure after prolonged aging. ${ }^{[1]}$ Asboll and Ryum, ${ }^{[7]}$ however, observed only precipitation of the equilibrium $\mathrm{D}_{22}$ phase in chillcast $\mathrm{Al}-0.34$ at. pct Ti alloys aged between $400{ }^{\circ} \mathrm{C}$ and $550{ }^{\circ} \mathrm{C}$. They also noted that the decomposition kinetics of $\mathrm{Al}_{3} \mathrm{Ti}$ were sluggish compared with those of $\mathrm{Al}$ alloyed with other elements of the same subgroup, $\mathrm{Zr}$ or 
Hf. Pandey and Suryanarayana ${ }^{[78]}$ also compared the decomposition behavior of rapidly solidified Al alloyed with $\mathrm{Ti}, \mathrm{Zr}$, or Hf (Group 4 elements) and noted that a metastable $\mathrm{Al}_{3} \mathrm{M}\left(\mathrm{Ll}_{2}\right)$ ordered phase is observed in $\mathrm{Al}-\mathrm{Zr}$ and Al-Hf alloys but not in Al-Ti alloys. This result agrees with other studies ${ }^{[8,32,43]}$ reporting only precipitation of the equilibrium $\mathrm{D}_{22}$ phase in $\mathrm{Al}-\mathrm{Ti}$ alloys aged in the broad temperature range of $200{ }^{\circ} \mathrm{C}$ to $600{ }^{\circ} \mathrm{C}$.

Other studies report no precipitation during aging of supersaturated Al-Ti solid solutions. Ohashi et al. ${ }^{[79]}$ found no evidence for precipitation of $\mathrm{Al}_{3} \mathrm{Ti}$, using microhardness and electrical resistivity measurements, in $\mathrm{Al}-\mathrm{Ti}$ alloys containing up to 0.45 at. pct Ti produced by RSP during 100 hours of aging in the range of $400{ }^{\circ} \mathrm{C}$ to $640{ }^{\circ} \mathrm{C}$. St. John et al. ${ }^{[31]}$ also observed no solid-state precipitation of $\mathrm{Al}_{3} \mathrm{Ti}$ when aging an $\mathrm{Al}-1.1$ at. pet $\mathrm{Ti}$ alloy for 24 hours at $435^{\circ} \mathrm{C}$; their alloy did, however, contain coarse primary $\mathrm{Al}_{3} \mathrm{Ti}$ precipitates, indicating that the amount of $\mathrm{Ti}$ initially in solid solution was reduced.

Nucleation of coherent $\mathrm{Al}_{3} \mathrm{Ti}\left(\mathrm{L}_{2}\right)$ precipitates has been reported only for highly supersaturated alloys produced by nonequilibrium means (RSP). Ohashi and Ichikawa ${ }^{[51]}$ observed $\mathrm{Al}_{3} \mathrm{Ti}\left(\mathrm{L}_{2}\right)$ precipitates in alloys containing 0.3 to 1.4 at. pct Ti aged at $400{ }^{\circ} \mathrm{C}$ to $500{ }^{\circ} \mathrm{C}$. Muddle and co-workers ${ }^{4,39,80,81]}$ observed precipitation of coherent $\mathrm{Al}_{3} \mathrm{Ti}\left(\mathrm{Ll}_{2}\right)$ in melt-spun alloys containing 2.9 to 3.5 at. pct $\mathrm{Ti}$ aged at $300{ }^{\circ} \mathrm{C}$ to $500{ }^{\circ} \mathrm{C}$. Similar supersaturations cannot be achieved by conventional casting (Figures 1 and 8) because Ti precipitates in the liquid as properitectic $\mathrm{Al}_{3} \mathrm{Ti}$ at moderate cooling rates.

\section{E. Common Industrial Uses of Ti and $\mathrm{Zr}$ Additions to Al}

Perhaps the most illustrative comparison of Al-Ti and $\mathrm{Al}-\mathrm{Zr}$ alloys is found by considering their primary industrial roles. As discussed, minor additions of Ti are used to refine the grain structure in commercial aluminum alloys, where primary $\mathrm{Al}_{3} \mathrm{Ti}$ precipitates act as heterogeneous nuclei during solidification of the melt. ${ }^{[19-22]}$ A solid-state counterpart to this grain refinement effect is realized when dilute additions of $\mathrm{Zr}$ are added to commercial wrought alloys as recrystallization inhibitors. ${ }^{[82-85]}$ Small (20 to $30 \mathrm{~nm}$ ) coherent $\mathrm{Al}_{3} \mathrm{Zr}$ $\left(\mathrm{Ll}_{2}\right)$ precipitates, formed during post-solidification aging, are effective barriers to grain-boundary migration. Titanium is thus added to form primary precipitates in the melt, whereas $\mathrm{Zr}$ is used to form coherent dispersoids precipitated from supersaturated solid solution. This suggests that (1) $\mathrm{Zr}$, compared with $\mathrm{Ti}$, is easier to retain in solid solution during conventional solidification; and (2) $\mathrm{Al}_{3} \mathrm{Zr}$, compared with $\mathrm{Al}_{3} \mathrm{Ti}$, is more readily precipitated during post-solidification aging. These considerations indicate that the $\mathrm{Al}-\mathrm{Zr}$ system is a better candidate than the Al-Ti system for developing a castable, precipitation-strengthened alloy.

\section{CONCLUSIONS}

This investigation has compared the decomposition of supersaturated, conventionally cast Al-0.2 at. pet Ti and
Al-0.2 at. pet $\mathrm{Zr}$ alloys, upon aging at $375{ }^{\circ} \mathrm{C}$ or $425{ }^{\circ} \mathrm{C}$. The $\mathrm{Zr}$-containing alloy exhibits a strong age hardening response after about 24 hours at both temperatures, due to copious precipitation of coherent, nanometer-scale $\mathrm{Al}_{3} \mathrm{Zr}\left(\mathrm{Ll}_{2}\right)$ precipitates within the supersaturated dendritic cells of the alloy. Precipitation of a similar $\mathrm{Al}_{3} \mathrm{Ti}$ phase in supersaturated dendrites is not observed, even for much longer aging times (up to 3200 hours at $425^{\circ} \mathrm{C}$ ). Compared with $\mathrm{Al}_{3} \mathrm{Zr}$, nucleation of $\mathrm{Al}_{3} \mathrm{Ti}$ $\left(\mathrm{L}_{2}\right)$ is hindered by the following: (1) a reduced chemical driving force $\left(\Delta F_{c h}\right)$ for nucleation (for a given local alloy composition, $\left.C_{0}\right)$; (2) a larger elastic strain energy opposing nucleation $\left(\Delta F_{e l}\right)$; and (3) a greater activation enthalpy for solute diffusion, $Q$.

Despite $\mathrm{Ti}$ enrichment in dendritic regions, the minimum supersaturation to produce solid-state $\mathrm{Al}_{3} \mathrm{Ti}$ precipitation cannot be achieved in conventionally solidified binary Al-Ti alloys because increasing the $\mathrm{Ti}$ concentration beyond the levels we have studied causes crystallization of primary $\mathrm{Al}_{3} \mathrm{Ti}$ during solidification and thus does not increase the solute available in solid solution for subsequent precipitation. By contrast, the $\mathrm{Al}-\mathrm{Zr}$ system is more promising for developing a castable, precipitation-hardened alloy with good coarsening and creep resistance.

\section{ACKNOWLEDGMENTS}

This research was supported by the United States Department of Energy, Basic Sciences Division, under Contract No. DE-FG02-02ER45997. Gratitude is expressed to KB Alloys for providing the Al-Zr master alloy. We are indebted to Dr. J.L. Murray (Alcoa), for providing the most recent and reliable data for the binary Al-Ti and Al-Zr phase diagrams. We also thank Dr. J.Z. Liu and Professor M. Asta (Northwestern University and University of California, Davis), for calculating the metastable $\mathrm{L}_{2}$ solvus curves for $\mathrm{Al}_{3} \mathrm{Ti}$ and $\mathrm{Al}_{3} \mathrm{Zr}$, and Professor M.E. Fine (Northwestern University) for useful discussions.

\section{REFERENCES}

1. K.E. Knipling, D.C. Dunand, and D.N. Seidman: Z. Metallkd., 2006, vol. 97 , pp. $246-65$.

2. H. Jones and W.M. Rainforth: Metall. Mater. Trans. A, 2003, vol. 34A, pp. 419-21

3. J.F. Nie, S. Sridhara, and B.C. Muddle: Metall. Trans. A, 1992, vol. 23A, pp. 3193-205.

4. J.F. Nie, A. Majumdar, and B.C. Muddle: Mater. Sci. Eng. A, 1994, vol. 179, pp. 619-24.

5. J.F. Nie and B.C. Muddle: Mater. Sci. Eng. A, 1996, vol. 215, pp. $92-103$.

6. W.E. Frazier and M.J. Koczak: in High Strength Powder Metallurgy Aluminum Alloys II, G.J. Hildeman and M.J. Koczak, eds., TMS, Warrendale, PA, 1986, pp. 353-66.

7. J.M. Wu, S.L. Zheng, and Z.Z. Li: Mater. Sci. Eng. A, 2000, vol. 289 , pp. $246-54$.

8. Y. Wang, Z. Zhang, W. Wang, and X. Bian: Mater. Sci. Eng. A, 2004, vol. 366, pp. 17-24.

9. G.X. Liang, Z.C. Li, and E. Wang: J. Mater. Sci., 1996, vol. 31, pp. $901-04$. 
10. W.E. Frazier and M.J. Koczak: Scripta Metall., 1987, vol. 21, pp. 129-34.

11. G.S. Murty, M.J. Koczak, and W.E. Frazier: Scripta Metall., 1987, vol. 21, pp. 141-46.

12. J.A. Hawk, P.K. Mirchandani, R.C. Benn, and H.G.F. Wilsdorf: in Dispersion Strengthened Aluminum Alloys, Y.W. Kim and W.M. Griffith, eds., TMS, Warrendale, PA, 1988, pp. 551-72.

13. J.A. Hawk, K.R. Lawless, and H.G.F. Wilsdorf: Scripta Metall., 1989, vol. 23, pp. 119-24.

14. J.A. Hawk, J.K. Briggs, and H.G.F. Wilsdorf: in Advances in Powder Metallurgy, T.G. Gasbarre and W.F. Jandeska, eds., MPIF, Princeton, NJ, 1989, pp. 285-99.

15. P.K. Mirchandani, R.C. Benn, and K.A. Heck: in Lightweight Alloys for Aerospace Applications, E.W. Lee, E.H. Chia and N.J. Kim, eds., TMS, Warrendale, PA, 1989, pp. 33-58.

16. P.K. Mirchandani, D.O. Gothard, and A.I. Kemppinen: in Advances in Powder Metallurgy, T.G. Gasbarre and W.F. Jandeska, eds., MPIF, Princeton, NJ, 1989, pp. 161-73.

17. S.H. Wang and P.W. Kao: Acta Mater., 1998, vol. 46, pp. 267582.

18. I.C. Barlow, H. Jones, and W.M. Rainforth: Acta Mater., 2001, vol. 49 , pp. 1209-24.

19. T. Ohashi and R. Ichikawa: Z. Metallkd., 1973, vol. 64, pp. $517-$ 21.

20. F.A. Crossley and L.F. Mondolfo: Trans. AIME, 1951, vol. 191, pp. $1143-48$

21. D.G. McCartney: Int. Mater. Rev., 1989, vol. 34, pp. 247-60.

22. B.S. Murty, S.A. Kori, and M. Chakraborty: Int. Mater. Rev., 2002, vol. 47, pp. 3-29.

23. W. Dahl, W. Gruhl, W.G. Burchard, G. Ibe, and C. Dumitrescu: Z. Metallkd., 1977, vol. 68, pp. 121-27.

24. S. Hori, S. Saji, and A. Takehara: in Proc. 4th Int. Conf. on Rapidly Quenched Metals, T. Masumoto and K. Suzuki, eds., The Japan Institute of Metals, Sendai, Japan, 1981, pp. 1545-48.

25. S. Hori and N. Furushiro: in Proc. 4th Int. Conf. on Rapidly Quenched Metals, T. Masumoto and K. Suzuki, eds., The Japan Institute of Metals, Sendai, Japan, 1981, pp. 1525-28.

26. S. Hori, N. Furushiro, and W. Fujitani: J. Jpn. Inst. Light Met., 1980, vol. 30, pp. 617-25.

27. A.F. Norman and P. Tsakiropoulos: Int. J. Rapid Solid., 1991, vol. 6 , pp. $185-213$.

28. W.L. Fink, K.R. van Horn, and P.M. Budge: AIMME Trans., 1931, vol. 93, pp. 421-39.

29. H.A.F. El-Halfawy, E.S.K. Menon, M. Sundararaman, and P. Mukhopadhyay: Metallography, 1979, vol. 12, pp. 257-62.

30. H.A.F. El-Halfawy: in Titanium '80-Science and Technology-4th Int. Conf. on Titanium, H. Kimura and O. Izumi, eds., TMS, Warrendale, PA, 1980, pp. 1379-87.

31. D.H. St John and L.M. Hogan: J. Mater. Sci., 1980, vol. 15, pp. $2369-75$.

32. K. Venkateswarlu, S.K. Das, M. Chakraborty, and B.S. Murty: Mater. Sci. Eng. A, 2003, vol. 351, pp. 237-43.

33. N.F. Levoy and J.B. Vander Sande: Metall. Trans. A, 1989, vol. 20A, pp. 999-1019.

34. P. Malek, M. Janecek, and B. Smola: Kov. Mater., 2000, vol. 38 , pp. $160-77$.

35. K.E. Knipling, D.C. Dunand, and D.N. Seidman: unpublished research, 2007.

36. H.W. Kerr, J. Cisse, and G.F. Bolling: Acta Metall., 1974, vol. 22, pp. $677-86$.

37. H.W. Kerr and W. Kurz: Int. Mater. Rev., 1996, vol. 41, pp. 129 64.

38. D.H. St. John and L.M. Hogan: J. Mater. Sci., 1982, vol. 17, pp. 2413-18.

39. J.F. Nie and B.C. Muddle: Mater. Sci. Eng. A, 1996, vol. 221, pp. 11-21.

40. B.S. You and W.W. Park: Scripta Mater., 1996, vol. 34, pp. 20105 .

41. T. Ohashi and R. Ichikawa: J. Jpn. Inst. Met., 1970, vol. 34, pp. 604-10.

42. V. Dobatkin, V.I. Elagin, V.M. Federov, and R.M. Sizova: Russ. Metall., 1970, pp. 122-27.

43. W.W. Park and T.H. Kim: J. Kor. Inst. Met., 1985, vol. 3, pp. 1118.
44. W.W. Park and T.H. Kim: Scripta Metall., 1988, vol. 22, pp. 1709-14.

45. R. Ichikawa and T. Ohashi: J. Jpn. Inst. Light Met., 1968, vol. 18, pp. 314-19.

46. T. Sato, A. Kamio, and G.W. Lorimer: Mater. Sci. Forum, 1996, vols. 217-222, pp. 895-900.

47. H. Okamoto: Phase Diagrams of Dilute Binary Alloys, ASM INTERNATIONAL, Materials Park, OH, 2002.

48. E. Babic, E. Girt, R. Krsnik, B. Leontic, M. Ocko, Z. Vucic, and I. Zoric: Physica Status Solidi A, 1973, vol. 16, pp. K21-K25.

49. E. Sahin and H. Jones: in Rapidly Quenched Metals II, B. Cantor, ed., The Metals Society, London, 1978, pp. 138-46.

50. J. Cisse, H.W. Kerr, and G.F. Bolling: Metall. Trans., 1974, vol. 5, pp. 633-41.

51. T. Ohashi and R. Ichikawa: J. Jpn. Inst. Light Met., 1977, vol. 27, pp. $105-12$.

52. O.A. Setiukov and I.N. Fridlyander: Mater. Sci. Forum, 1996, vols. 217-222, pp. 195-200.

53. N. Ryum: J. Mater. Sci., 1975, vol. 10, pp. 2075-81.

54. M.F. Ashby and L.M. Brown: Phil. Mag., 1963, vol. 8, pp. 10831102.

55. V.L. Nordheim: Ann. Phys., 1931, vol. 9, pp. 641-78.

56. J. Royset and N. Ryum: Mater. Sci. Eng. A, 2005, vol. 396, pp. 409-22.

57. M.E. van Dalen, D.C. Dunand, and D.N. Seidman: Acta Mater., 2005, vol. 53, pp. 4225-35.

58. K.E. Knipling, D.C. Dunand, and D.N. Seidman: Microsc. Microanal., 2006, accepted for publication.

59. J.L. Murray: Alcoa, Alcoa Center, PA, personal communication, 2005.

60. J.L. Murray, A. Peruzzi, and J.P. Abriata: J. Phase Equil., 1992, vol. 13, pp. 277-91.

61. J.Z. Liu:, Ph.D. Thesis, Northwestern University, Evanston, IL, 2006.

62. J.Z. Liu, G. Ghosh, A. van de Walle, and M. Asta: Phys. Rev. B, 2007, vol. 75, p. 104117.

63. G.W. Lorimer and R.B. Nicholson: Mechanism of Phase Transformations in Crystalline Solids, Session II, Institute of Metals, London, 1969, pp. 36-42.

64. K.C. Russell: in Phase Transformations, H.I. Aaronson, ed., ASM, Metals Park, OH, 1970, pp. 219-68.

65. R.D. Doherty: in Physical Metallurgy, R.W. Cahn and P. Haasen, eds., Elsevier, Amsterdam, 1983, pp. 933-1030.

66. H.I. Aaronson and F.K. LeGoues: Metall. Trans. A, 1992, vol. 23A, pp. 1915-45.

67. R. Wagner, R. Kampmann, and P.W. Voorhees: in Phase Transformations in Materials, G. Kostorz, ed., Wiley-VCH, New York, NY, 2001, pp. 309-407.

68. B. Chalmers: Principles of Solidification, John Wiley \& Sons, New York, NY, 1964, pp. 126-28.

69. M.C. Flemings: Solidification Processing, McGraw-Hill, New York, NY, 1974, pp. 31-32.

70. W. Kurz and D.J. Fisher: Fundamentals of Solidification, 4th ed., Trans Tech Publications, Aedermannsdorf, Switzerland, 1998, p. 15.

71. H.J. Frost and M.F. Ashby: Deformation-Mechanism Maps: The Plasticity and Creep of Metals and Ceramics, Pergamon Press, New York, NY, 1982, p. 21.

72. M.A. Meyers and K.K. Chawla: Mechanical Metallurgy: Principles and Applications, Prentice-Hall, Englewood Cliffs, NJ, 1984 , p. 58

73. Y. Harada and D.C. Dunand: Scripta Mater., 2003, vol. 48, pp. 219-22.

74. J. Royset and N. Ryum: Scripta Mater., 2005, vol. 52, pp. 127579.

75. S. Hori, H. Tai, and Y. Narita: J. Jpn. Inst. Light Met., 1982, vol. 32, pp. 596-603.

76. S. Hori, H. Tai, and Y. Narita: in Rapidly Quenched Metals, S. Steeb and H. Warlimont, eds., Elsevier Science Publishers, Wurzburg, 1985, pp. 911-14.

77. K. Asboll and N. Ryum: J. Inst. Met., 1973, vol. 101, pp. 212-14.

78. S.K. Pandey and C. Suryanarayana: Mater. Sci. Eng. A, 1989, vol. 111, pp. 181-87.

79. T. Ohashi, K. Suzuki, and R. Ichikawa: Bull. Nagoya Inst. Technol., 1971, vol. 23, pp. 459-65. 
80. A. Majumdar, R.H. Mair, and B.C. Muddle: in Science and Technology of Rapidly Quenched Alloys, M. Tenhover, W.L. Johnson and L.E. Tanner, eds., MRS, Pittsburgh, PA, 1987, pp. 253-60.

81. J.F. Nie and B.C. Muddle: Mater. Sci. Eng. A, 1996, vol. 221, pp. 22-32.
82. N. Ryum: Acta Metall., 1969, vol. 17, pp. 269-78.

83. M. Sundberg, R. Sundberg, and B. Jacobson: Jernkont. Ann., 1971, vol. 155, pp. 1-15.

84. S. Rystad and N. Ryum: Aluminium, 1977, vol. 53, pp. 193-95.

85. H. Westengen, L. Auran, and O. Reiso: Aluminium, 1981, vol. 57, pp. 797-803 